\title{
Infestation rate with polyplax spinulosa (burmeister, 1839) among certain laboratory albino rats (rattus norvegicus) in relation to different washing agents in two Erbil city universities
}

Received: 9/8/2010

Accepted: 29/11/2010

\begin{abstract}
Qaraman M.K. Koyee* $\quad$ Rezan K. Ahmed* Kawa K. Aziz* Hardi Sh. Ahmed* Aryan H. Abdula*
\section{Abstract}

Backgrounds and objectives: The ectoparasite Polyplax spinulosa (Class: Isecta; SubOrder: Anoplura; Familiy: Polyplacidae) was found to act as a biological vector of some pathogenic virus, bacteria and protozoa. The main objective of the present study was to identify the $P$. spinulosa parasitizing laboratory rats in two different animal houses (Science College-Salahaddin University and Medicine College-Hawler Medical University) and the effect of washing with different detergent agents on the mean intensity and numbers of the Polyplax spinulosa.

Methods: In a study from the beginning of February to July 2010, thirty (30) adult Albino rats (15 rats from each Science and Medicine Colleges) randomly were collected from two selected animal houses of two universities in Erbil City. The fur was gently examined and scraped off using a fine brush; hair particles and ectoparasites that dropped off were transferred to a petridish, and examined using magnifying lenses and dissecting microscope before and after washing with two different agents. The ectoparasites collected in small vials were fixed in $70 \%$ ethanol.

Results: The overall prevalence with the $P$. spinulosa was $80 \%$, the higher rate of infestation $(100 \%)$ and mean intensity (13.33) was among rats of Science College, while the lower rate $(60 \%)$ and mean intensity (4) was among rats of Medicine College. The present study showed that Cis-Cypermethrin has greater role than Cyprimidine in declining the rate of infestation with this ectoparasite.

Conclusion: The overall prevalence with the $P$. Spinulosa was $80 \%$, The higher rate of infestation was among rats of Science College. Cis-Cypermethrin has a role in declining the rate of infestation with this ectoparasite.

Key word: Polyplax spinulosa, laboratory rats, washing agents, Erbil.

\section{Introduction}

Synanthropic rodents, particularly those living in close association with man, play a significant role in human health and economy. It has to be stressed that their arthropod ectoparasites are important vectors of pathogenic microorganisms and they can also be important reservoirs ${ }^{1}$. Many rodents are implicated in the spread of diseases to humans and domestic animals. The causative organisms of many diseases are carried in the blood of rodents and need an arthropod vector to act as an intermediary in the transmission of the diseases to man. The development of control methods against zoonotic parasites is dependent on knowledge of their life cycles and transmission pattern in each zoogeographical condition ${ }^{2}$. Early researches were primarily lists of hosts and their ectoparasite species and taxonomic studies, but little has been published about the ectoparasite infestation parameters. The sucking louse genus Polyplax Enderlein, 1904 is well represented in the world 3,4 . P. serrata

* Biology Department, Science College, Salahaddin University, Erbil, Iraq 
(Burmeister, 1839) and P. spinulosa (Burmeister, 1839) have accompanied introduced mice and rat respectively, and are now widespread throughout much of the world $^{5}$. The ectoparasite $P$. spinulosa was found to be act as a biological vector of some pathogenic virus, bacteria and protozoa ${ }^{6}$. A total number of 12 Rattus spp trapped in wet markets in Quiapo, Manila and Balayan, Batangas had ectoparasites, Echinolaelaps echidnius (mite), and $P$. spinulosa (louse). Eight $(67.0 \%)$ and five $(42.0 \%)$ of the rats had infestation with the mite $E$. echidnius and louse $P$. spinulosa, respectively, manifesting heavy and mixed infestation in some rats ${ }^{7}$. The sanitary condition of 13 animal houses in nine public institutions in Minas Gerais, and the presence of ectoparasites of rats colonies kept in these facilities were evaluated. Parasitological results have shown that only one animal house $(7.7 \%)$ had parasite free animals, whereas the others have presented infected animals ${ }^{8}$. A total number of 17 rats ( $R$. rattus) were examined from two related sites in Kandy District for detecting ectoparasites; there was no recording of $P$. spinulosa in their study ${ }^{9}$, while 77 rodents were captured in Bandar Abbas, Southern Iran, among all rodents $40.3 \%$ were found infested with ectoparasites, $P$. spinulosa was considered as a lice ectoparasite ${ }^{10}$. Little information is available on the laboratory rat ectoparasites in Kurdistan Region generally and Erbil city Universities specially. The objectives of the work reported here:-

1. Identify the $P$. spinulosa parasitizing laboratory rats in two different animal houses (Science College-Salahaddin University, and Medicine College-Hawler Medical University).

2. Compare the prevalence of $P$. spinulosa infestation in both animal houses in relation to washing period.

\section{Methods}

\section{Animals and housing}

During the February to July 2010, thirty (30) adult albino rats (Rattus norvegicus) were obtained from two animal houses, fifteen rats from each of Science College, Salahaddin University and Medicine College, Hawler Medical University. Animals were housed in plastic cages bedded with wooden chips. They were housed under standard laboratory conditions, 12:12 light/ dark photoperiod (LD) at $22 \pm 2{ }^{\circ} \mathrm{C}{ }^{11}$. The animals were given standard rat pellets and tap water ad libitum. The rats were examined before and after the same washing period (monthly) with different washing agents (Cyprimidine and Cis-Cypermethrin of Science and Medicine Colleges respectively).

\section{Anesthetization}

The rats were anesthetized intraperitonially with ketamine hydrochloride $(50 \mathrm{mg} / \mathrm{kg})^{12}$.

\section{Examination}

The fur was gently examined and scraped off using a fine brush; hair particles and ectoparasites that dropped off were transferred to a Petri dish, and examined using magnifying lenses and dissecting microscope. The ectoparasites collected in small vials were fixed in $70 \%$ ethanol for further examination by light microscope.

\section{Criteria of infection}

The ecological terms (Prevalence and mean intensity of infestation) were used here based on the terminology of Margolis et $a l^{13}$ :

Prevalence of infestation: The percentage of number of individuals of a host species infested with a particular parasite species/ Number of hosts examined.

Mean intensity of infestation: Mean number of individuals of a particular parasite per infested hosts in a sample.

\section{Photomicrography}

Photographs of the parasites were taken in a digital-camera (Cyber-Shot, Sony, 8.1 megapexl).

\section{Parasite identification}

The detected parasites were identified according to their morphology, Illustration, morphological descriptions aid in the analysis of the distinctive characters and ultimately in the identification of most of parasitic forms (ectoparasites) encountered ${ }^{14,15 .}$ 


\section{Results}

In two selected animal houses of Erbil City Universities (Science College-Salahaddin University and Medicine College-Hawler Medical University), a total of 30 laboratory albino rats (Rattus norvegicus) were examined for infestation with $P$. spinulosa (Figure. 1). The Occurrence of $P$. spinulosa in rat colonies of the previous mentioned animal houses showed in Table (1), the total number of isolated $P$. spinulosa were 36 and 200 among examined rats of Medicine and Science colleges respectively. The mean intensity of $P$. spinulosa infestation was 13.33 and 4 among rats of Science, and Medicine Colleges respectively, with the overall 9.83 for both as shown in (Table 2). The results of the $P$. spinulosa infestation rate among rats of two selected animal houses in relation to pre- and post washing with two different agents (CisCypermethrin and Cypremidine) showed in (Table 3) and (Figure 2), its clear, through observation that all examined rats before washing with the previous mentioned washing agents from two selected animal houses were infested $100 \%$ with $P$. spinulosa, while the infestation rate decline among rats of Medicine College (60\%) after washing with Cis-Cypermethrin when compared with those washed with Cypremidine which were $100 \%$.

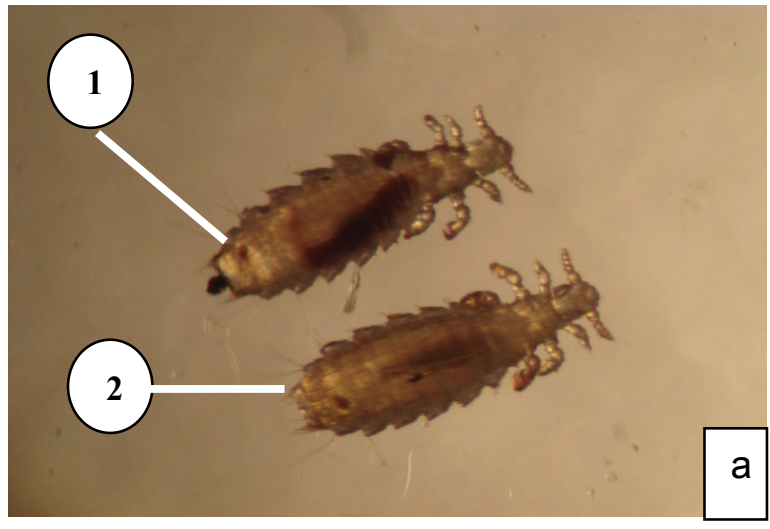

Figure 1: a. Photomicrograph of Polyplax spinulosa (adult) 100x.

a-1 Adult male Polyplax spinulosa.

a-2 Adult female Polyplax spinulosa

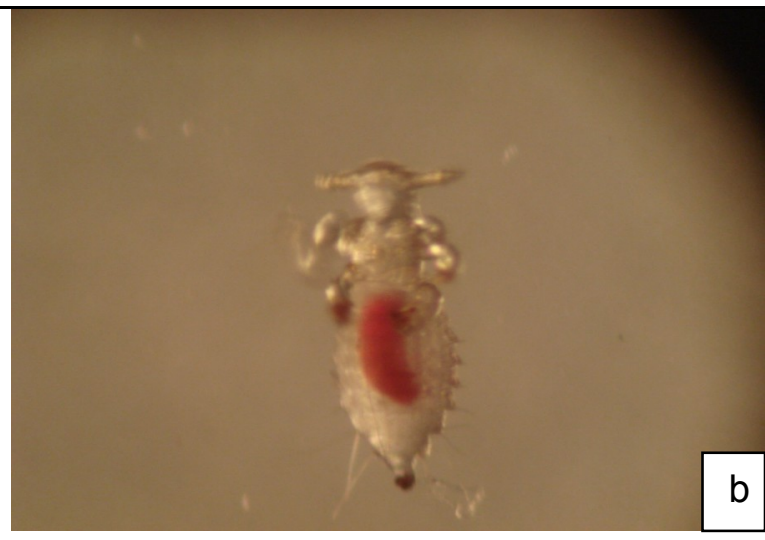

b. Photomicrograph of female Polyplax spinulosa (blood feeding) 100x.

Table 1: Occurrence of Polyplax spinulosa in rat colonies in two selected animal houses investigated in Erbil city.

No. of isolated

Host No. Polyplax spinulosa

\begin{tabular}{ccc}
\cline { 2 - 3 } & $\begin{array}{c}\text { Science } \\
\text { College }\end{array}$ & $\begin{array}{c}\text { Medicine } \\
\text { College }\end{array}$ \\
\hline 1 & 42 & 3 \\
2 & 18 & 5 \\
3 & 47 & - \\
4 & 25 & - \\
5 & 10 & 3 \\
6 & 13 & 4 \\
7 & 3 & 3 \\
8 & 14 & - \\
9 & 5 & 6 \\
10 & 4 & - \\
11 & 2 & - \\
12 & 5 & - \\
13 & 4 & 6 \\
14 & 3 & 3 \\
15 & 5 & 36 \\
Total & 200 &
\end{tabular}


Table 2: Mean intensities of Polyplax spinulosa infestation of 30 examined laboratory rats in Hawler city.

\begin{tabular}{lccc} 
Animal houses & $\begin{array}{c}\text { No. of infested } \\
\text { animals }\end{array}$ & $\begin{array}{c}\text { Total no. of } \\
\text { p. spinulosa }\end{array}$ & Mean intensity \\
\hline College of Science & $15 / 15$ & 200 & 13.33 \\
College of Medicine & $9 / 15$ & 36 & 4 \\
Total & $24 / 30$ & 236 & 9.83
\end{tabular}

Table 3: Prevalence of $P$. spinulosa on 30 examined laboratory rats in relation to preand postwashing with two different washing agents in two Erbil-City Universities.

\begin{tabular}{lccccc} 
Animal houses & Washing agents & $\begin{array}{c}\text { Infested host } \\
\text { No. pre- wash- } \\
\text { ing }\end{array}$ & $\%$ & $\begin{array}{c}\text { Infested } \\
\text { host No. } \\
\text { post- } \\
\text { washing }\end{array}$ & $\%$ \\
\hline College of science & Cyprimidine & $15 / 15$ & $100 \%$ & $15 / 15$ & $100 \%$ \\
College of Medicine & $\begin{array}{c}\text { Cis-Cypermethrin } \\
\text { (Alvepoor) }\end{array}$ & $15 / 15$ & $100 \%$ & $9 / 15$ & $60 \%$ \\
Total & - & $30 / 30$ & $100 \%$ & $24 / 30$ & $80 \%$
\end{tabular}

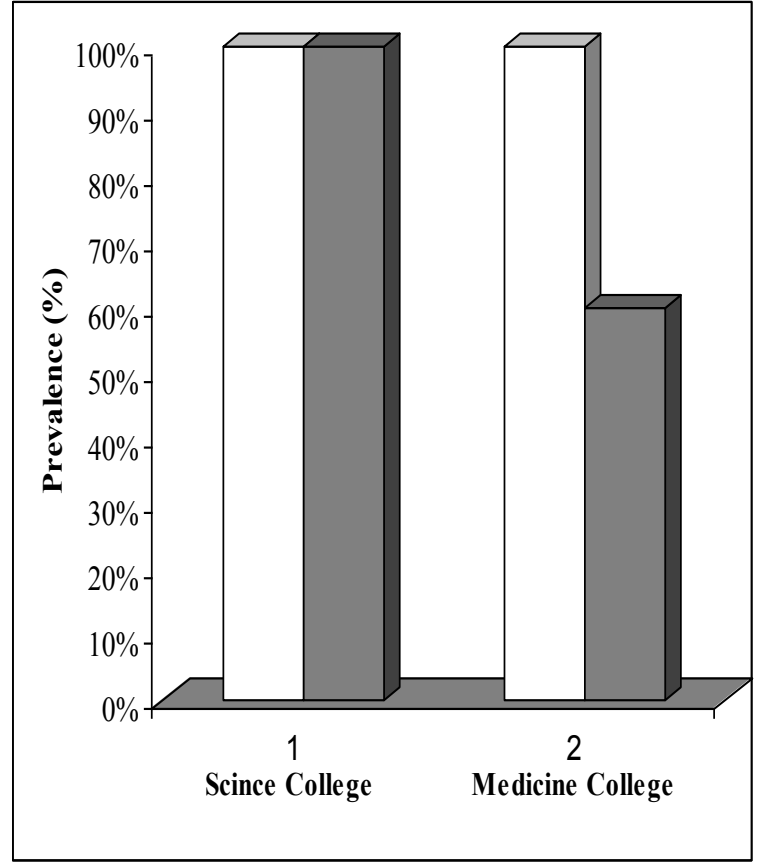

Figure 2: Percentage of infested rats by $P$. spinulosa in relation to pre- and Postwashing with two different washing agents in two Erbil-City Universities.

\section{Discussion}

Ectoparasites are irritating pests of humans and animals and may be vectors of zoonotic pathogens that cause diseases such as bacterial and viral diseases ${ }^{16}$. Polyplax spinulosa, the spined rat louse, is a blood sucking louse which completes its life cycle on the host. Clinical signs include anemia, unthrifty appearance, scratching, and small skin wounds. It can transmit a number of infectious agents. Transmission is by direct contact ${ }^{15}$. The result of the occurrence of $P$. spinulosa in rat colonies in two selected animal houses is inagreement with the study done by ${ }^{17}$, in which they mentioned that the distribution of lice on the rats was very irregular, even when rats were caught at the same time and on the same premises. Some of them harbored numerous lice, others one or two only, and same frequently carried none at all. Furthermore, high parasite mean intensity was expected in Science college animal house in comparison with Medicine College, due to the small building area when compared 
to the high rat numbers, crowdy caging and poor sanitary conditions. This result is inagreement with ${ }^{6,8}$, they reported that the sanitary conditions in different animal houses have a role in parasite free animals, and also the lack of facilities devices, expertise and rigorous sanitary barriers associated with poor management in animal houses enable dissemination of pathogenic agents detected within and among colonies mentioned in breeding rooms. The infestation rate decline among rats of Medicine College after washing with CisCypermethrin when compared with those washed with Cypremidine, this result may be explained by using unsuitable and incorrect washing agent (Cypremidine), which is antibacterial and antifungal, while CisCypermethrin is specific for the control and killing ectoparasites as its labeled on their containers .

\section{Conclusion}

1. The overall prevalence with the $P$. Spinulosa was $80 \%$.

2. In this study it was found that the higher rate of infestation was among examined laboratory rats of Science College, while the lower rate was among rats of Medicine College.

3. Cis-Cypermethrin has a role in declining the rate of infestation with this ectoparasite.

\section{Recommendations}

1. Determine the suitable insecticide and washing period for eradicating $P$. spinulosa and other ectoparasites.

2 . Due to the existence of $P$. spinulosa on rats in the studied area, more studies be needed to evaluate the way of their transmission and disease productions.

\section{References}

1.Stojcevic D, Mihaljevic Z, Marinculic A. Parasitological survey of rats in rural regions of Croatia, Vet. Med. - Czech. 2001; 49 (3): 70-4.

2. Kia EB, Homayouni MM, Farahnak A, Mohebali M, Shojai S. Study of Endoparasites of Rodents and their Zoonotic Importance In Ahvaz, South West Iran. Iranian J. Publ. HIth. 2001;30 (1-2): 49-52.
3. Durden LA, Musser GG. The sucking licelnsecta, (Anoplora) of the world: a taxonomic checklist with records of mammalian hosts and geographical distributions. Bull. Am. Mus. Nat. Hist. 1994; 208: 1 $-90$

4. Chin TH. A new species of sucking louse from Cricetulus longicaudatus Milne-Edwards. Acta Zootaxonom. Sin. 1995; 20: 97-101.

5. Durden LA Eckerlin RP. Polyplax Guatemalensis sp. N. (Phthiraptera: Anoplora) a new sucking louse from Peromyscus grandis, a montane cloud forest rodent from Guatemala, Folia parasitol. 2001; 48: 69-72.

6. Gilioli R. Avaliação do perfil sanitário de colônias de camundongos e de ratos em biotérios brasileiros: ocorrência de bactérias, parasitas e vírus murinos. 138f. Tese (Doutorado) - Instituto de Biologia, Universidade Estadual de Campinas, Campinas, SP. 2003.

7. Claveria FG, Causapin J, Guzman MA, Toledo MG, Salibay C. Parasite biodiversity Rattus spp caught in wet markets. 2005; 36 (4): 146-148.

8. Bicalho KA, Araújo FTM, Roch RS, Carvalho OS. Sanitary profile in mice and rat colonies in laboratory animal houses in Minas Gerais:Endo and ectoparasites, Arq. Bras. Med. Vet. Zootec. 2007; 59 (6):1478-1484

9. Sumangali K, Rajakaruna RS, Rajapakse RPVJ. Ecto and Endo Parasites of Rodents from Two Selected Sites in Kandy District, Proceedings of the Peradeniya University Research Sessions, Sri Lanka, 2007; Vol.12, Part I.

10. Kia EB, Sani HM, Hassanpoor $H$, Vatandoost $H$, Zahabiun F, Akhavan AA, Hanafi-Bojd AA Telmadarraiy Z. Ectoparasites of Rodents Captured in Bandar Abbas, Southern Iran Iranian J ArthropodBorne Dis. 2009; 3(2): 44-49.

11. Coskun O, Ocakci A, Bayraktaroglu T, Kanter M. Exercise training prevents and protects streptozotocin-induced oxidative stress and beta-cell damage in rat pancreas. Tohoku J. Exp.Med. 2004; 203,145-154.

12. Maulood IM. Effects of L-arginine and Melatonin on Plasma Endothelin-1 level in Rats with Induced Diabetes Mellitus or Pulmonary Fibrosis. Ph.D., Thesis. Salahaddin University. 2005; 113pp.

13. Margolis L, Esch GW, Holmes JC, Kuris AM, Schad GA. The use of ecological terms in parasitology (Report of an ad hoc committee of the American Society of Parasitologists). J. Parasitol. 1982; 68 (1): 131-133.

14. Dasgupta B. Parasitology (including Entomologyand Acarology).1st Publ., Books and Allied (P) Ltd. India. 2000.

15. Sharp PE, La Regina MC. The Laboratory Rat. CRC Press, London. Chapter 4. 1998.

16. Nelder MP, Reeves WK. Ectoparasites of roadkilled vertebrates in northwestern South Carolina, USA Veter. Parasitol. 2005; 129: 313-322. 
17. Mooser H, Castaneda MR Zinsser HJ. The transmission of the virus of Mexican typhus from rat to rat by Polyplax spinulosus. Am. Med. Assn. $1931 ; 97-231$. 